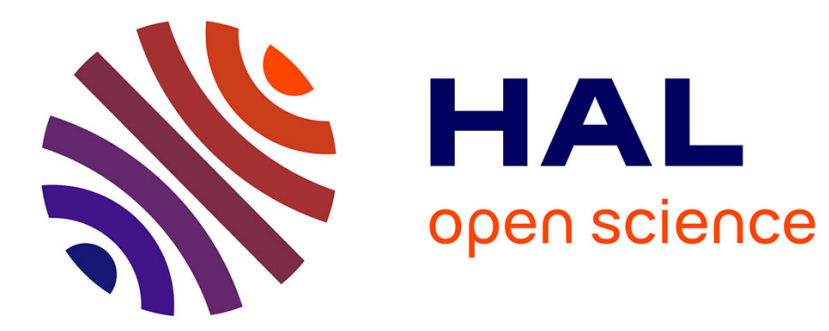

\title{
Flexible Template-Free RHO Nanosized Zeolite for Selective CO 2 Adsorption
}

Julien Grand, Nicolas Barrier, Maxime Debost, Edwin Clatworthy, Fabien

Laine, Philippe Boullay, Nikolai Nesterenko, Jean-Pierre Dath, Jean-Pierre

Gilson, Svetlana Mintova

\section{To cite this version:}

Julien Grand, Nicolas Barrier, Maxime Debost, Edwin Clatworthy, Fabien Laine, et al.. Flexible Template-Free RHO Nanosized Zeolite for Selective CO 2 Adsorption. Chemistry of Materials, 2020, 32 (14), pp.5985-5993. 10.1021/acs.chemmater.0c01016 . hal-02968421

\section{HAL Id: hal-02968421 \\ https://hal.science/hal-02968421}

Submitted on 26 Nov 2020

HAL is a multi-disciplinary open access archive for the deposit and dissemination of scientific research documents, whether they are published or not. The documents may come from teaching and research institutions in France or abroad, or from public or private research centers.
L'archive ouverte pluridisciplinaire HAL, est destinée au dépôt et à la diffusion de documents scientifiques de niveau recherche, publiés ou non, émanant des établissements d'enseignement et de recherche français ou étrangers, des laboratoires publics ou privés. 


\title{
Flexible Template-Free RHO Nanosized Zeolite for Selective $\mathrm{CO}_{2}$ Adsorption
}

\author{
Julien Grand ${ }^{\dagger}$ Nicolas Barrier, ${ }^{\dagger *}$ Maxime Debost, ${ }^{\dagger}$ Edwin B. Clatworthy ${ }^{\dagger}$ Fabien Lainé, ${ }^{\star}$ Philippe Boul- \\ lay, ${ }^{\ddagger}$ Nikolai Nesterenko, ${ }^{\Perp}$ Jean-Pierre Dath, ${ }^{\|}$Jean-Pierre Gilson, ${ }^{\dagger}$ Svetlana Mintova ${ }^{\dagger *}$ \\ $\dagger$ Normandie Université, ENSICAEN, UNICAEN, CNRS, Laboratoire Catalyse et Spectrochimie (LCS), 14050 Caen, \\ France \\ † Normandie Université, ENSICAEN, UNICAEN, CNRS, Laboratoire de Cristallographie et Science des Matériaux \\ (CRISMAT), 14050 Caen, France
}

\| Total Research and Technology, Feluy, B-7181 Seneffe, Belgium

\begin{abstract}
Flexible small-pore zeolites are interesting candidates for flue and natural gas processing due to their high sorption capacity and selectivity. It is generally accepted that their high $\mathrm{CO}_{2} / \mathrm{CH}_{4}$ selectivity is due to cation gating behavior such as the "trapdoor" effect or cation-controlled molecular sieving. Herein, nanosized RHO-type zeolite containing only inorganic cations $\left(\mathrm{Na}^{+}\right.$ and $\mathrm{Cs}^{+}$) has been prepared from a colloidal precursor suspension at $90{ }^{\circ} \mathrm{C}$ for $1 \mathrm{~h}$ without the use of expensive organic structure directing agents. The high Cs content significantly improved the thermal stability of the RHO nanocrystals up to $550{ }^{\circ} \mathrm{C}$. The flexibility of the RHO cages upon water adsorption/desorption is demonstrated. The dehydration of the nanosized RHO zeolite resulted in two dehydrated RHO phases, the first one presents an enlargement of the cubic unit cell and a transformation from distorted to the more regular $d 8 r$ units, and the second one presents a reduction of the cubic unit cell and an increase of the distortion of the $d 8 r$ units. The 8-rings elliptical distortions of the as synthesized RHO (hydrated form) of $1.87 \AA$ changed to $0.94 \AA$ and $2.16 \AA$ for the two dehydrated RHO forms. The flexibility of the nanosized RHO zeolite is due to the ability of the $\mathrm{Cs}^{+}$cation to displace out from and in to the D8R window sites which is of great importance for controlling the selective adsorption capacity of the RHO zeolite. The flexible RHO-type nanosized zeolite exhibited great selectivity towards $\mathrm{CO}_{2}$ over $\mathrm{CH}_{4}$. The adsorption capacity is retained after 10 cycles of $\mathrm{CO}_{2}$ adsorption/desorption and the crystalline structure is fully preserved.
\end{abstract}

\section{- INTRODUCTION}

Zeolite materials are microporous crystalline solids possessing networks of channels and cages. As of 2019 the number of approved structure types is 249 , of which 25 have been prepared with nanosized dimensions. Reducing the particle size of zeolites from the micro to the nanoscale leads to significant changes in their properties such as an increase in the external surface area and reduced diffusion path length, enhancing the accessibility of guest molecules to active sites within the micropores and cages. ${ }^{1}$ Several methods for the synthesis of nanosized zeolites have been developed in recent years including post-synthesis modification, one-step hydrothermal crystallization in the presence of mesopore modifiers, and synthesis with organic structure directing agents (OSDAs). ${ }^{2}$ The synthesis of nanosized zeolites without OSDAs is an important research target because the post-synthetic removal of OSDAs requires additional energy, generates emissions $\left(\mathrm{CO}_{\mathrm{x}}, \mathrm{NO}_{\mathrm{x}}\right)$, and can reduce the crystallinity of the zeolite which negatively impacts their performance. ${ }^{3-4}$

Zeolite frameworks, composed of $\mathrm{SiO}_{4}{ }^{4-}$ and $\mathrm{AlO}_{4}{ }^{5-}$ tetrahedra, maintain charge neutrality by the presence of extra-framework cations, the most common of which are $\mathrm{Na}^{+}$and $\mathrm{K}^{+}$. In addition to providing charge neutrality, extra-framework cations have also been shown to influence the zeolite crystallization process; acting as inorganic structure directing agents. ${ }^{5}$ For example, the presence of specific type and amount of cations, with or without the use of OSDAs, is required to facilitate the formation of
RHO-type zeolites as reported by several groups ${ }^{6-7}$ In particular, it has been shown that not only is the presence of $\mathrm{Cs}^{+}$cations required, but a specific mixture of $\mathrm{Na}^{+}$and $\mathrm{Cs}^{+}$is necessary to avoid the formation of other zeolite phases such as FAU or ANA. $^{8}$

Due to the change in global energy demands, there is an increasing need for porous materials able to separate the components of natural gas, mainly $\mathrm{CH}_{4}$ and $\mathrm{CO}_{2}$. In this context small pore zeolites are interesting candidates due to their high sorption capacity and $\mathrm{CO}_{2} / \mathrm{CH}_{4}$ selectivity. The RHO topology is constructed from $d 8 r$ units that act as windows to lta cages resulting in two 3D interpenetrating but unconnected pore systems. ${ }^{9}$ RHO-type zeolites have promising applications in catalysis and gas separation, ${ }^{10}$ NOx removal, ${ }^{7}$ MTO reactions, ${ }^{6,}, 11$ and $\mathrm{CO}_{2} / \mathrm{CH}_{4}$ separation. ${ }^{12-14}$ Furthermore, the synthesis of zeolites with high adsorption selectivity and nanoparticle morphology creates new opportunities in medical applications for the targeted delivery of therapeutic gases. ${ }^{15}$ The origin of the high selectivity for $\mathrm{CO}_{2}$ is a combination of the narrow pore size (3.6 $\AA$ ) and the presence of different extra-framework cations, such as $\mathrm{Na}^{+}$and $\mathrm{Cs}^{+}$, which sit in the pores and restrict access to the internal cages. ${ }^{16}$ The ability of extra-framework cations to selectively control the access of molecules to the zeolite channels is described as cation gating and may occur through different mechanisms: the "trapdoor" effect and molecular sieving. The proposed "trapdoor" effect ${ }^{17}$ occurs due to the ability of molecules which possess a relatively large quadrupole moment and 
polarizability, such as $\mathrm{CO}_{2}$ as compared to $\mathrm{N}_{2}$ or $\mathrm{CH}_{4}$, to displace extra-framework cations from the pore opening. However, other studies propose the interaction of $\mathrm{CO}_{2}$ with the zeolite and the amplitude of the thermal motion of the extra-framework cations is responsible for allowing $\mathrm{CO}_{2}$ into the cage while blocking $\mathrm{N}_{2}$ and $\mathrm{CH}_{4}{ }^{18}$ Molecular sieving of gas mixtures by zeolite RHO occurs due to the influence of extra-framework cations on the framework structure resulting in changes to the pore size. In addition, temperature, the presence of water, and adsorption of $\mathrm{CO}_{2}$ have also been reported to affect zeolite RHO structure. $^{19-22}$

Herein, we present the first synthesis of nanosized flexible RHO-type zeolites without the use of expensive OSDAs or seeds. Highly crystalline nanoparticles of zeolite RHO were obtained using inorganic structure directing agents, $\mathrm{Na}^{+}$and $\mathrm{Cs}^{+}$ cations, only. The zeolite RHO nanocrystals have a diameter of less than $70 \mathrm{~nm}$ and the framework structure and position of the cations have been determined by Rietveld refinement based on XRD patterns. The distortion of the $d 8 r$ units as well as the displacement of the $\mathrm{Na}^{+}$and $\mathrm{Cs}^{+}$cations within the cages upon adsorption of water and $\mathrm{CO}_{2}$ was studied by temperature dependent in situ XRD.

\section{- EXPERIMENTAL}

Synthesis. RHO-type nanosized zeolite was prepared by hydrothermal synthesis from a colloidal precursor suspension using the following chemicals without further purification: sodium aluminate $\left(53 \% \mathrm{Al}_{2} \mathrm{O}_{3} 47 \% \mathrm{Na}_{2} \mathrm{O}\right.$ by mass, Sigma-Aldrich), colloidal silica LUDOX AS40 (40\% by mass in water, SigmaAldrich), sodium hydroxide (99\%, Sigma-Aldrich) and cesium hydroxide ( $98 \%$, Alfa-Aesar). Doubly deionized water was used throughout the synthesis and post-synthesis treatments. Syntheses were carried out in $100 \mathrm{~cm}^{3}$ polypropylene bottle (PP bottle) at autogenous pressure without agitation up to $100{ }^{\circ} \mathrm{C}$ and in autoclave above $100^{\circ} \mathrm{C}$.

A clear colloidal suspension was prepared by mixing $516 \mathrm{mg}$ of sodium aluminate in $3 \mathrm{~g}$ of $\mathrm{dd}_{2} \mathrm{O}$. $1.82 \mathrm{~g}$ of sodium hydroxide and $588 \mathrm{mg}$ of cesium hydroxide were added to the clear suspension. During the mixing, the suspension was maintained at room temperature (i.e. $25^{\circ} \mathrm{C}$ ) while being stirred vigorously. The stirring at room temperature was continued for at least $2 \mathrm{~h}$ and afforded a clear (colloidal) aqueous alkali aluminate suspension. $5 \mathrm{~g}$ of LUDOX AS4O was added dropwise to the clear suspension. During the addition it was maintained at room temperature while being vigorously stirred. The $\mathrm{pH}$ of the resulting clear aqueous suspension was about 12 . The resulting clear aqueous suspension with a molar composition, $10 \mathrm{SiO}_{2}: 0.8$ $\mathrm{Al}_{2} \mathrm{O}_{3}: 8 \mathrm{Na}_{2} \mathrm{O}: 0.58 \mathrm{Cs}_{2} \mathrm{O}: 100 \mathrm{H}_{2} \mathrm{O}$, was then aged on a magnetic stirrer for $14 \mathrm{~h}$ at room temperature. Then, the hydrothermal crystallization was conducted at $90{ }^{\circ} \mathrm{C}$ for $1 \mathrm{~h}$ so as nanocrystals RHO zeolite was synthesized. The solid was separated and recovered by high-speed centrifugation (20000 rpm, 10 $\mathrm{min}$ ) and purified with hot double distilled water (heated at 100 ${ }^{\circ} \mathrm{C}$ for $30 \mathrm{~min}$ ) until the $\mathrm{pH}$ of the decanting water was about 7.5. Further in the paper, the as synthesized nanosized RHO zeolite sample in hydrated form will be abbreviated as NaCs$\mathrm{RHO}\left(\mathrm{H}_{2} \mathrm{O}\right)$ and the dehydrated sample at high temperature (350 ${ }^{\circ} \mathrm{C}$ ) will be abbreviated as NaCs-RHO.

Characterization. The powder X-ray diffraction (PXRD) patterns were measured on a Bruker D8 Advance Vario1 diffractometer equipped with a primary germanium (111) Johansson monochromator $(\lambda \mathrm{K} \alpha 1=1.5406 \AA)$ and a LynxEye detector.
The PXRD patterns were collected at room temperature with variable divergent slits and constant illuminated sample length of $6 \mathrm{~mm}$, between 5 and $120^{\circ} 2 \theta$ with a step of $\sim 0.014^{\circ} 2 \theta$. Temperature-dependent powder in situ X-ray diffraction (TDPXRD) patterns were recorded on the same diffractometer with an Anton Paar HTK1200N chamber, under a flow of $\mathrm{N}_{2}$ (the first pattern was recorded at $350{ }^{\circ} \mathrm{C}$ with the same conditions as the previous one). Dehydration and hydration of the RHO samples were also performed between 30 and $300{ }^{\circ} \mathrm{C}$ in air. In situ $\mathrm{CO}_{2}$ adsorption was also followed by TD-PXRD. The samples were pre-treated in situ at $350^{\circ} \mathrm{C}$ under $\mathrm{N}_{2}$ atmosphere for $2 \mathrm{~h}$ to remove the adsorbed water. The $\mathrm{CO}_{2}$ flow (1 bar) was delivered at $350^{\circ} \mathrm{C}$ for $3 \mathrm{~h}$. Diffractograms were then recorded every $20{ }^{\circ} \mathrm{C}$ until $30{ }^{\circ} \mathrm{C}$ under a constant flow of $\mathrm{CO}_{2}$ (1 bar). The sample was maintained under $\mathrm{CO}_{2}$ for 10 hours to check any evolution of the amount of adsorbed $\mathrm{CO}_{2}$.

The whole profile matching of the PXRD diagrams were performed using the JANA2006 program $^{23}$ (the $I-43 m$ space group was used). The structures were solved using the $a b$ initio approach with the SUPERFLIP program ${ }^{24}$ and the Rietveld refinements were performed with the JANA2006 program assuming fundamental approach for peak-shape fitting and crystallites size determination (Table S1). All the atomic positions and isotropic displacement parameters $\left(\mathrm{U}_{\text {iso }}\right)$ were refined (Table $\mathrm{S} 2$ ). Anisotropic atomic displacement parameters (ADPs) were taken into consideration for all the Cs1 atoms of the double eight-rings (D8Rs) except for the NaCs-RHO-2 structure; in the latter, the refinements of the ADPs gave unrealistic values.

The crystal size and morphology of the samples were first characterized using a FEI Tecnai G30 $\left(\mathrm{LaB}_{6}, \mathrm{~V}_{\mathrm{acc}}=300 \mathrm{kV}\right)$ transmission electron microscope (TEM) on diluted colloidal suspensions of zeolite materials. High resolution transmission electron microscopy (HRTEM) was performed on a JEOL ARM 200F (cFEG, $\mathrm{V}_{\text {acc }}=200 \mathrm{kV}$ ) TEM.

Chemical composition was obtained by energy dispersive $\mathrm{X}$ Ray spectroscopy (EDS) using a JEOL $2010\left(\mathrm{LaB}_{6}, \mathrm{~V}_{\mathrm{acc}}=200\right.$ V) TEM. The chemical composition of the RHO samples was further confirmed by inductively coupled plasma (ICP) optical emission spectroscopy using a Varian ICP-OES 720-ES and by deconvolution of the ${ }^{29} \mathrm{Si}$ solid state MAS NMR signals using DMFIT software. The ${ }^{29} \mathrm{Si}$ solid state MAS NMR spectra were collected on a Bruker Avance III-HD 500 (11.7 T) spectrometer operating at $99.3 \mathrm{MHz}$, using 4-mm outer diameter zirconia rotors spun at $12 \mathrm{kHz}$. The ${ }^{27} \mathrm{Al}$ MAS NMR spectra were recorded on a Bruker Avance III-HD 500 (11.7 T) spectrometer operating at $130.3 \mathrm{MHz}$, using 4-mm outer diameter zirconia rotors spun at $14 \mathrm{kHz}$.

$\mathrm{N}_{2}$ adsorption/desorption isotherms were measured at $-196^{\circ} \mathrm{C}$ and $\mathrm{CO}_{2}$ adsorption isotherms were measured at $25^{\circ} \mathrm{C}$ using a Micrometrics Model ASAP 2020 volumetric adsorption analyzer. Samples were degassed at $300^{\circ} \mathrm{C}$ under vacuum for $12 \mathrm{~h}$ prior to analysis. Thermogravimetric analysis (TGA/DTG) of samples was carried out on a SETSYS 1750 CS evolution instrument (SETARAM). The samples were heated from $25^{\circ} \mathrm{C}$ to $800{ }^{\circ} \mathrm{C}$ with a heating ramp of $5{ }^{\circ} \mathrm{C} / \mathrm{min}$ under nitrogen (flow rate: $40 \mathrm{~mL} / \mathrm{min}$ ).

Cycles of $\mathrm{CO}_{2}$ adsorption/desorption were conducted 10 consecutive times by alternating between activation at $350{ }^{\circ} \mathrm{C}$ for 2 $\mathrm{h}$ under $\mathrm{N}_{2}$ flow (flow rate: $40 \mathrm{~mL} / \mathrm{min}$ ) and $\mathrm{CO}_{2}$ adsorption at room temperature (flow rate: $40 \mathrm{~mL} / \mathrm{min}, 1$ bar) for $2 \mathrm{~h} . \mathrm{CO}_{2}$ and $\mathrm{CH}_{4}$ adsorption on $\mathrm{RHO}$ was studied by in situ IR spectroscopy using a self-supported pellet $\left(10 \mathrm{mg} \cdot \mathrm{cm}^{-2}\right)$ of RHO; the 
transmission IR spectra were recorded with a Nicolet Avatar spectrometer. A room temperature IR-cell equipped with a heating device was used to activate the samples at $350{ }^{\circ} \mathrm{C}$ prior to the measurements. The cell was connected to a high vacuum line of $10^{-5} \mathrm{~Pa}$. The sample was activated at $100{ }^{\circ} \mathrm{C}$ for $0.5 \mathrm{~h}$ followed by heating at $350{ }^{\circ} \mathrm{C}$ for $3 \mathrm{~h}$ under high vacuum. All IR spectra were recorded at room temperature, $\mathrm{CO}_{2}$ cycling experiments were conducted under 1 bar of $\mathrm{CO}_{2}$. IR spectra were recorded on the sample under an atmosphere of equal volume, 1:1 of $\mathrm{CO}_{2}: \mathrm{CH}_{4}$ from 0 to 1 bar. The background spectra of the empty transmission cell was recorded under high vacuum at room temperature.

\section{- RESULTS AND DISCUSSION}

A whole profile matching of the PXRD pattern of sample NaCs$\mathrm{RHO}\left(\mathrm{H}_{2} \mathrm{O}\right)$ was performed considering the $I-43 m$ space group. The refined unit-cell parameter was $a=14.8118(1) \AA$. All reflections were indexed confirming a single polycrystalline phase. The structure was solved and the location of the $\mathrm{Na}^{+}$and $\mathrm{Cs}^{+}$cations were identified by ab initio approach (see the experimental section). All the atomic positions and isotropic displacement parameters $\left(U_{i s o}\right)$ were refined and summarized in Table S2. Atomic displacement parameters (ADPs) were taken into consideration for the $\mathrm{Cs} 1$ atom. The oxygen atoms of the water molecules were localized from Fourier difference maps. The final reliability factors obtained after the last refinement cycle are: $R_{\text {Fobs }}=4.87 \%$ and $R_{w p}=4.80 \%$ (see Figure 1 for the corresponding PXRD fit). The average size of the diffracting domains of sample $\mathrm{NaCs}-\mathrm{RHO}\left(\mathrm{H}_{2} \mathrm{O}\right)$ calculated from the Rietveld refinement is $57(1) \mathrm{nm}$. The size and morphology of

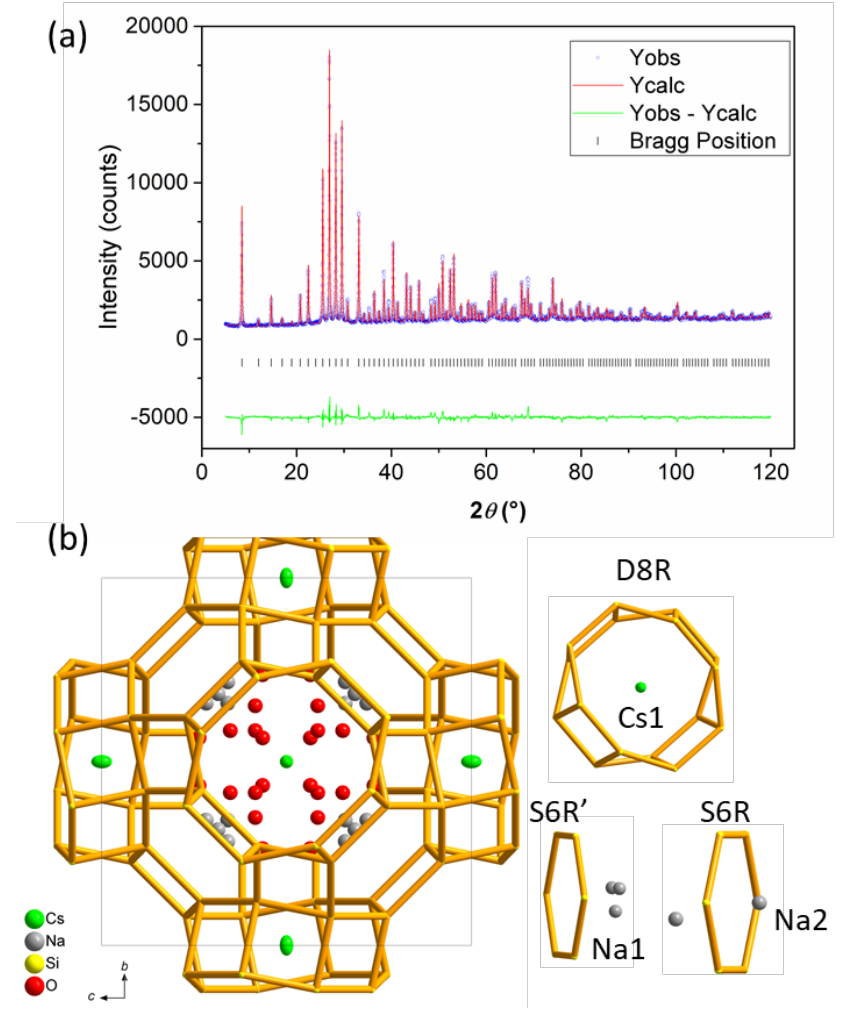

Figure 1. (a) Rietveld refinements from PXRD pattern of the nanosized NaCs- $\mathrm{RHO}\left(\mathrm{H}_{2} \mathrm{O}\right)$ zeolite sample. (b) Views of the RHO framework with the specified localization of $\mathrm{Cs}^{+}, \mathrm{Na}^{+}$and $\mathrm{O}$ atoms of the water molecules. Ellipsoids are drawn at the $50 \%$ probability level. the crystals were further studied by TEM (see below). The chemical composition of the $\mathrm{NaCs}-\mathrm{RHO}\left(\mathrm{H}_{2} \mathrm{O}\right)$ sample determined by ICP analysis, EDS, and TGA are similar: $\mathrm{Na}_{13.4} \mathrm{Cs}_{6.0} \mathrm{Si}_{28.5} \mathrm{Al}_{19.5} \mathrm{O}_{96} \quad 36 \mathrm{H}_{2} \mathrm{O} \quad$ (ICP/TGA), and $\mathrm{Na}_{13.7} \mathrm{Cs}_{6.5} \mathrm{Si}_{27.6} \mathrm{Al}_{20.4} \mathrm{O}_{96} 36 \mathrm{H}_{2} \mathrm{O}$ (EDS/TGA). The slight differences in the chemical composition is attributed to the different sensitivity of each technique. The results from the Rietveld refinements show the preferential site of the $\mathrm{Cs}^{+}$cations is in the center of the D8R windows, while $\mathrm{Na}^{+}$and water molecules are located in the lta cages, outside the single six-ring (S6R) window site (Figure 1b). The ability of the $\mathrm{Cs}^{+}$to move along the "8-fold"axis of the D8R is observed. Indeed, the anisotropic displacement parameter is larger along the "8-fold"axis of the D8Rs $\left(\mathrm{U}_{11}=\mathrm{U}_{/ /}=0.07335 \AA^{2}\right)$ compared to the perpendicular direction $\left(\mathrm{U}_{22}=\mathrm{U}_{\perp}=0.03114 \AA^{2}\right)$. The structure of the NaCs$\mathrm{RHO}\left(\mathrm{H}_{2} \mathrm{O}\right)$ was refined in the acentric $I-43 m$ cubic space group instead of the "ideal" centric Im-3m space group when the elliptical distortion of the D8Rs is taken into account. According to Parise et $\mathrm{al}^{25}$, the elliptical distortion, or ellipticity, of the D8Rs can be evaluated by a parameter $\Delta$, which corresponds to the $\mathrm{O} 1-\mathrm{O} 2$ distance projected on the (001) plane, i.e. the average of the difference between the longest and the shortest $\mathrm{O}-\mathrm{O}$ distances within the cross-section of the D8R, vide infra. For $\mathrm{NaCs}-\mathrm{RHO}\left(\mathrm{H}_{2} \mathrm{O}\right)$, with a formula $\mathrm{Na}_{13.1} \mathrm{Cs}_{5.2}\left(\mathrm{Si}_{29.7} \mathrm{Al}_{18.3} \mathrm{O}_{96}\right)\left(\mathrm{H}_{2} \mathrm{O}\right)_{41}, \Delta$ is $1.87 \AA$. This value is slightly larger than the one reported by Baur $\Delta=1.57 \AA .{ }^{26} \mathrm{Ac}$ cording to Corbin et al. ${ }^{19}$, the degree of distortion is related to the charge density of the cations located within the D8R windows. In this work, for $\mathrm{NaCs}-\mathrm{RHO}\left(\mathrm{H}_{2} \mathrm{O}\right)$ the occupancy factor of the $\mathrm{Cs}^{+}$cations sitting in the center of the D8R window site is larger than the one reported by Baur in agreement with a lower $\mathrm{Si} / \mathrm{Al}$ ratio. ${ }^{26}$ These extra-framework charge-compensating cations influence the distortion of the D8Rs, which is similar to the effect of temperature, ion-exchange or adsorption of different molecules in RHO-type zeolites. On the other hand, it has been shown that the high water content of the NaCs$\mathrm{RHO}\left(\mathrm{H}_{2} \mathrm{O}\right)$ sample is due to the higher $\mathrm{Si} / \mathrm{Al}$ ratio which can also influence the RHO framework, i.e. inducing a degree of flexibility. Similarly, the flexible structure of MER-type has been recently reported. The authors showed that the zeolite structure tunes itself to coordinate extra framework cations when dehydrated or upon $\mathrm{CO}_{2}$ uptake. ${ }^{27}$ In our case, the evolution of the unit cell parameter of $\mathrm{NaCs}-\mathrm{RHO}\left(\mathrm{H}_{2} \mathrm{O}\right)$ at room temperature under $\mathrm{N}_{2}$ flow was determined from the XRD data. It varies from 14.810 to $14.778 \AA$ with a decrease in the unit cell volume from 3248.5 to $3227.2 \AA^{3}$ after $10 \mathrm{~h}$ of continuous exposure to $\mathrm{N}_{2}$ (Figure $\mathrm{S} 1$ ).

The thermal stability of the as-synthesized $\mathrm{NaCs}-\mathrm{RHO}\left(\mathrm{H}_{2} \mathrm{O}\right)$ sample is studied. The PXRD patterns of as synthesized and calcined sample at $550{ }^{\circ} \mathrm{C}$ and $650{ }^{\circ} \mathrm{C}$ are shown in Figure $2 \mathrm{a}$. Bragg peaks corresponding to the RHO-type framework only were present in all patterns of the samples, as-prepared and after the calcination (Figure 2). Partial amorphization of the NaCs$\mathrm{RHO}\left(\mathrm{H}_{2} \mathrm{O}\right)$ sample after treatment at $650{ }^{\circ} \mathrm{C}$ was observed; approximately $60 \%$ of the crystallinity was retained as determined from the XRD patterns obtained after calcination at $650{ }^{\circ} \mathrm{C}$. Ionexchange with $\mathrm{NH}_{4} \mathrm{Cl}$ followed by thermal treatment at $400{ }^{\circ} \mathrm{C}$ resulted in the collapse of the structure, demonstrating that the presence of the $\mathrm{Cs}^{+}$cations improves the thermal stability of the zeolite (Figure S2). The distortion of the $\mathrm{NaCs}-\mathrm{RHO}\left(\mathrm{H}_{2} \mathrm{O}\right)$ zeolite was further investigated by NMR. ${ }^{29} \mathrm{Si}$ and ${ }^{27} \mathrm{Al}$ MAS NMR spectra of the sample $\mathrm{NaCs}-\mathrm{RHO}\left(\mathrm{H}_{2} \mathrm{O}\right)$ before and after calcination at $550{ }^{\circ} \mathrm{C}$ were found to be identical, confirming no 
removal of Al from the zeolite framework (Figure 2). Single peaks corresponding to tetrahedrally coordinated $\mathrm{Al}$ were observed at $60 \mathrm{ppm}$, and no peak at $0 \mathrm{ppm}$ corresponding to octahedrally coordinated $\mathrm{Al}$ was present (Figure $2 \mathrm{c})$. The $\mathrm{Q}^{0}(4 \mathrm{Al})$, $\mathrm{Q}^{1}(3 \mathrm{Al}), \mathrm{Q}^{2}(2 \mathrm{Al}), \mathrm{Q}^{3}(1 \mathrm{Al})$ and $\mathrm{Q}^{4}(0 \mathrm{Al})$ species at $-84 \mathrm{ppm},-88$ ppm, $-92 \mathrm{ppm},-98 \mathrm{ppm}$ and $-102 \mathrm{ppm}$, respectively are present in the spectrum of NaCs-RHO( $\left.\mathrm{H}_{2} \mathrm{O}\right)$ (Figure $2 \mathrm{c}$ ). Using the ${ }^{29} \mathrm{Si}$ spectra, the $\mathrm{Si} / \mathrm{Al}$ ratio of the as synthesized $\mathrm{NaCs}-\mathrm{RHO}\left(\mathrm{H}_{2} \mathrm{O}\right)$ zeolite is calculated to be 1.50. Additional EDS and ICP analyses confirmed the $\mathrm{Si} / \mathrm{Al}$ ratio of the sample to be in the range
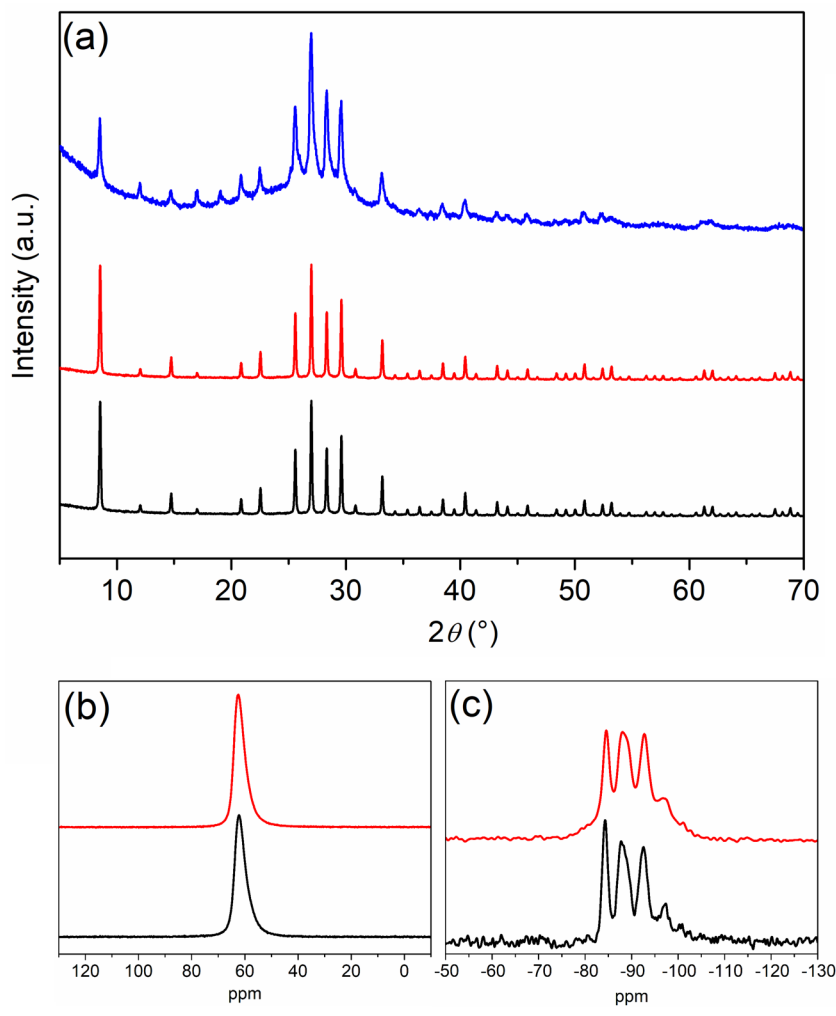

Figure 2. (a) PXRD patterns of as synthesized nanosized NaCs$\mathrm{RHO}\left(\mathrm{H}_{2} \mathrm{O}\right)$ (black), and after calcination at $550{ }^{\circ} \mathrm{C}$ (red) and at 650 ${ }^{\circ} \mathrm{C}$ (blue); (b) ${ }^{27} \mathrm{Al}$ NMR and (c) ${ }^{29} \mathrm{Si}$ NMR NMR spectra of assynthesized $\mathrm{NaCs}-\mathrm{RHO}\left(\mathrm{H}_{2} \mathrm{O}\right)$ (black) and after calcination at 550 ${ }^{\circ} \mathrm{C}$ (red).
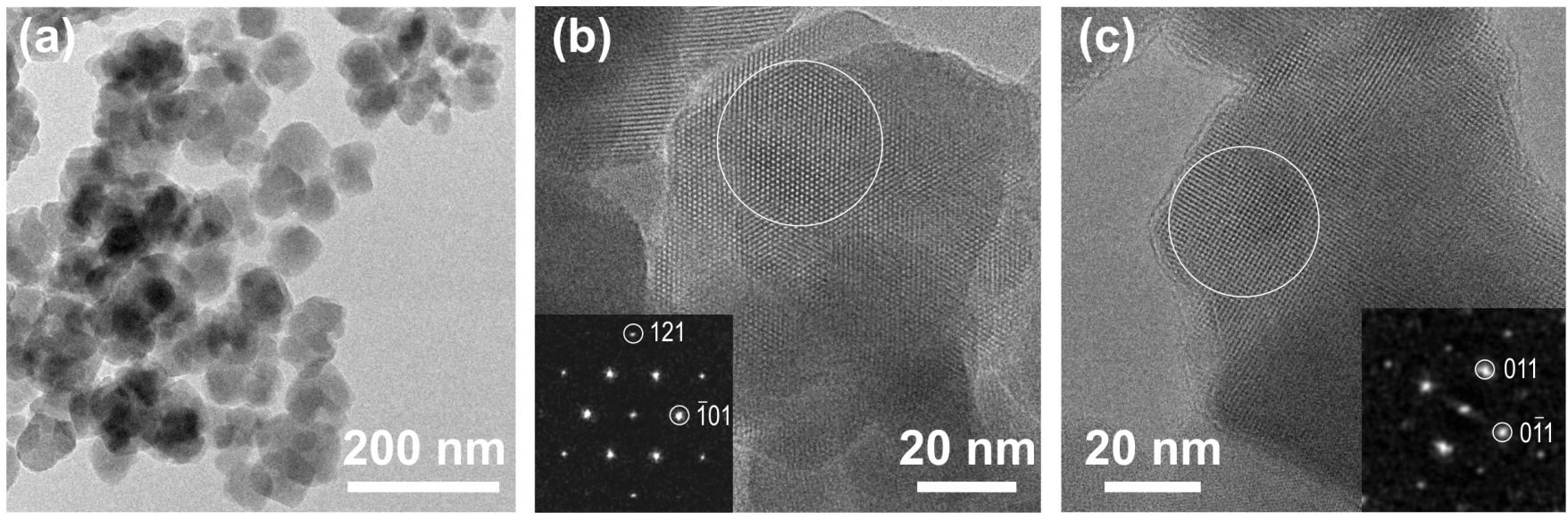

Figure 3. TEM images of nanosized RHO-type zeolites at different magnifications. (a) TEM image showing the homogeneous crystal size. (b) and (c) HRTEM images revealing the high crystallinity of the sample, insets show the FFT from the areas encircled in white corresponding to [1-11] and [100] oriented crystals, respectively (SG: $I-43 m$ ). of 1.4-1.5. TEM images reveal uniform nanosized crystals with a size of less than $100 \mathrm{~nm}$ in diameter (Figure 3). The as synthesized RHO nanocrystals have low microporosity due to the presence cations $\left(\mathrm{Na}^{+}, \mathrm{Cs}^{+}\right)$that block access of $\mathrm{N}_{2}$ to the micropores (Figure S3). However, the comparatively high total pore volume is attributed to the interparticle mesoporosity. Nanosized crystals with a uniform size distribution and a high external surface area form regular interparticle mesopores when dried.

\section{Flexibility of Nanosized RHO Zeolite upon Dehydra- tion.}

The flexibility of the nanosized RHO zeolite upon hydration/dehydration was studied using in situ XRD. The XRD patterns of sample $\mathrm{NaCs}-\mathrm{RHO}\left(\mathrm{H}_{2} \mathrm{O}\right)$ subjected to heating from 30 to 300 ${ }^{\circ} \mathrm{C}$ and subsequent cooling to $30{ }^{\circ} \mathrm{C}$ were collected in air and under $\mathrm{N}_{2}$ flow (Figure 4). Overall, fully reversible dehydration was observed for the $\mathrm{NaCs}-\mathrm{RHO}\left(\mathrm{H}_{2} \mathrm{O}\right)$ sample; a splitting of the peak at $8.45^{\circ} 2 \theta$ under heating of the sample at $180^{\circ} \mathrm{C}$ was measured, while during the cooling to $120^{\circ} \mathrm{C}$ the splitting disappeared. The dehydration of the nanosized RHO-type zeolite is accompanied by an enlargement of the cubic unit cell and a transformation of the RHO structure from the distorted $d 8 r$ units ( $I-43 m$ acentric space group) to the more regular $d 8 r$ units (Im-3m centrosymmetric space group). This phenomenon was observed previously for RHO-type zeolites subjected to very high pressure ${ }^{28}$ or during the adsorption of $\mathrm{CO}_{2}{ }^{16}$ The enlargement of the unit cell can be seen clearly in the PXRD patterns, i.e. the (101) reflection at $8.5^{\circ} 2 \theta$ shifts towards higher degrees $2 \theta$. In the case of the sample $\mathrm{NaCs}-\mathrm{RHO}\left(\mathrm{H}_{2} \mathrm{O}\right)$, the (101) reflection splits in two when the sample is heated above $120^{\circ} \mathrm{C}$ (Figure 4). The splitting of the reflection remains present up to $300{ }^{\circ} \mathrm{C}$. A complementary PXRD experiment performed until $440{ }^{\circ} \mathrm{C}$ showed that there is no evolution of the position and intensity of the split (101) reflection under heating from 270 to $440{ }^{\circ} \mathrm{C}$ (Figure S4). Initially, it was suspected that water was retained in the $\mathrm{NaCs}-\mathrm{RHO}\left(\mathrm{H}_{2} \mathrm{O}\right)$ zeolite sample up to $300{ }^{\circ} \mathrm{C}$. However, the TGA results showed complete dehydration of the sample above $300{ }^{\circ} \mathrm{C}$ (Figure S5). Alternatively, it was considered that the splitting of the reflections could be due to a lowering of the symmetry. However, the diffraction peaks above 120 ${ }^{\circ} \mathrm{C}$ can only be indexed by two RHO cubic unit cells with 
(a) Dehydration

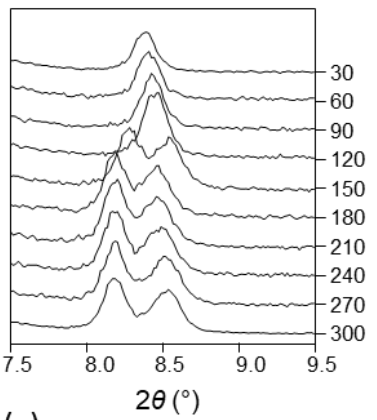

(b) Rehydration

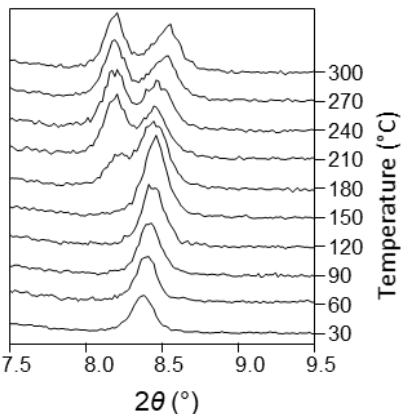

(c)

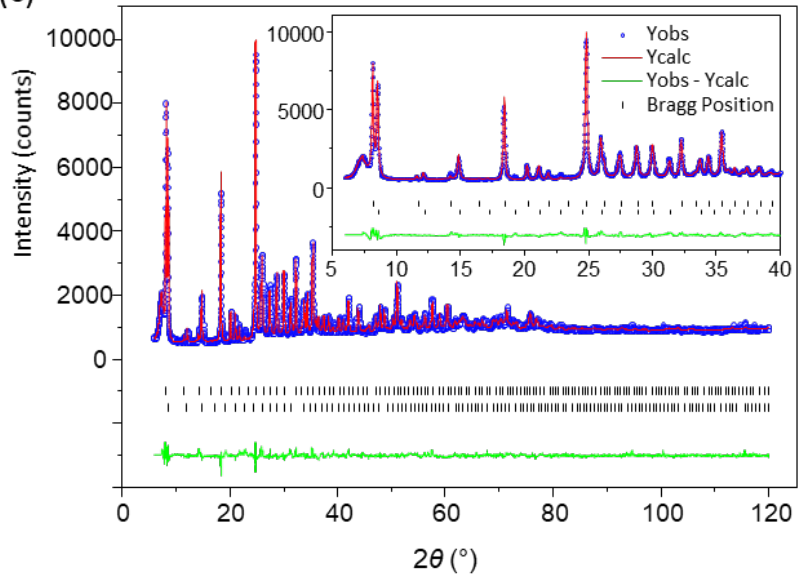

Figure 4. In situ PXRD patterns of nanosized $\mathrm{NaCs}-\mathrm{RHO}\left(\mathrm{H}_{2} \mathrm{O}\right)$ zeolite recorded in air upon (a) heating from 30 to $300{ }^{\circ} \mathrm{C}$ (dehydration process), and (b) cooling from 300 to $30{ }^{\circ} \mathrm{C}$ (rehydration process); (c) Rietveld refinement of the PXRD pattern of nanosized $\mathrm{NaCs}-\mathrm{RHO}$ zeolite collected at $350{ }^{\circ} \mathrm{C}$ under $\mathrm{N}_{2}$ atmosphere.

different values for the lattice parameter, $a=15.1603(3) \AA$ and $a=14.5179(5) \AA$. It appears that two different dehydrated RHO phases are present at high temperature $\left(350^{\circ} \mathrm{C}\right)$, compared to the presence of one structure after rehydration at lower temperature $\left(<150^{\circ} \mathrm{C}\right)$. To investigate this unexpected and completely reversible behavior, the structural analysis of the NaCs-RHO samples was conducted by assuming the existence of two phases (NaCs-RHO-1 and NaCs-RHO-2). The coexistence of two structural phases has been observed previously for NaCs-, $\mathrm{K}-$ and Cs-RHO in response to changes in applied the pressure of $\mathrm{CO}_{2} \cdot{ }^{13,16}$ According to Parise et al. ${ }^{25}$ the decrease of the unit cell parameter corresponds to an increase in the elliptical distortion of the D8Rs and the structure retaining the acentric $I$ $43 \mathrm{~m}$ symmetry. Conversely, with the enlargement of the unit cell, the elliptical distortion of the D8Rs decreases and the structure acquires the centric $I m-3 m$ symmetry. With these considerations, both structures were first solved and refined, considering the space groups $I m-3 m$ for the phase with the largest unit cell (NaCs-RHO-1), and $I-43 m$ for the phase with the smallest unit cell (NaCs-RHO-2). The obtained figures of merit $\left(\mathrm{R}_{\mathrm{Fobs}}-1=\right.$ $6.38 \% ; \mathrm{R}_{\text {Fobs }}-2=6.32 \%$ and $\mathrm{R}_{\mathrm{wp}}=5.37 \%$ ) were further improved by considering the $I-43 \mathrm{~m}$ space group for both phases leading to the final result with: $\mathrm{R}_{\mathrm{Fobs}}-1=4.39 \% ; \mathrm{R}_{\mathrm{Fobs}}-2=4.31 \%$ and $\mathrm{R}_{\mathrm{wp}}=4.39 \%$. The two different RHO frameworks related to NaCs-RHO-1 and NaCs-RHO-2 are shown in Figure 5. The chemical formulas determined from the Rietveld refinements for the phases NaCs-RHO-1 and NaCs-RHO-2 are $\mathrm{Na}_{7.4} \mathrm{Cs}_{11.0}\left(\mathrm{Si}_{29.6} \mathrm{Al}_{18.4}\right) \mathrm{O}_{96}$ and $\mathrm{Na}_{13.5} \mathrm{Cs}_{2.6}\left(\mathrm{Si}_{31.9} \mathrm{Al}_{16.1}\right) \mathrm{O}_{96}$ with the mass concentrations of 49(1) and 51(1)\%, respectively. An increase of the elliptical distortion of the D8Rs from $\Delta=1.87$ $\AA$ for $\mathrm{NaCs}-\mathrm{RHO}\left(\mathrm{H}_{2} \mathrm{O}\right)$ to $\Delta=2.16 \AA$ for NaCs-RHO-2 is observed (Figure 6). This is comparable to the value calculated for pure Na-RHO reported earlier $(\Delta=2.10 \AA$ with a unit cell parameter of $a=14.4139(2) \AA)$. ${ }^{19,24}$ The structure of NaCs-RHO2 is similar to the hydrated $\mathrm{NaCs}-\mathrm{RHO}\left(\mathrm{H}_{2} \mathrm{O}\right)$ zeolite sample and similar to the dehydrated structure reported in the literature. ${ }^{12}$ Both the $\mathrm{Cs}^{+}$and $\mathrm{Na}^{+}$cations can occupy the same locations as in the hydrated sample, i.e. inside the $\mathrm{D} 8 \mathrm{R}$ window and outside of the S6R window respectively. However, the amount of $\mathrm{Cs}^{+}$ in the sample $\mathrm{NaCs}-\mathrm{RHO}-2$ is reduced in comparison to the as synthesized hydrated $\mathrm{NaCs}-\mathrm{RHO}\left(\mathrm{H}_{2} \mathrm{O}\right)$ sample. The occupancy factor of $\mathrm{Cs}^{+}$in the D8R window site decreased from 0.863 to 0.323 . A small amount of $\mathrm{Cs}^{+}(0.080)$ is also present on the $\mathrm{Na} 1$ S6R window site. On the other hand, the unit cell parameter of sample NaCs-RHO-1 increased to 15.1603(3) $\AA$, corresponding to a decrease in the elliptical distortion with $\Delta=0.94 \AA$. To the best of our knowledge this is the largest unit cell parameter reported for the RHO type zeolite structure. The amount of $\mathrm{Cs}^{+}$ increases from 5.2 in the as synthesized $\mathrm{NaCs}-\mathrm{RHO}\left(\mathrm{H}_{2} \mathrm{O}\right)$ to 11.0 in the NaCs-RHO-1 phase. Such a large amount of $\mathrm{Cs}^{+}$ cannot stay in the central D8R window site. The $\mathrm{Cs}^{+}$cations move out from the D8R window site to reside in the lta cages, i.e. in front of the D8R. Again, we can notice the large anisotropic displacement of the $\mathrm{Cs}^{+}$cations along the "8-fold" axis of the D8Rs (Figure 5a) $\left(\mathrm{U}_{/ /}=0.291(6) \AA^{2}\right.$ and $U_{\perp}=0.070(2)$ $\AA^{2}$ ). The ability of the $\mathrm{Cs}^{+}$cations to be displaced in and out of the D8Rs is the basis for the change of the selective adsorption ability of RHO, which is described as "trapdoor" behavior. The opposite displacement was observed for $\mathrm{Na}^{+}$, from outside to inside of the S6R. It appears that all of the $\mathrm{Cs}^{+}$and $\mathrm{Na}^{+}$cations are inside the lta cages, replacing the water molecules, and thus stabilizing the zeolite framework. After rehydration of the sample at room temperature, the PXRD pattern was identical to that of the as-synthesized $\mathrm{NaCs}-\mathrm{RHO}\left(\mathrm{H}_{2} \mathrm{O}\right)$ nanosized zeolite. It is hypothesized that two RHO phases are present in the as synthesized sample, however, it is difficult to differentiate them due
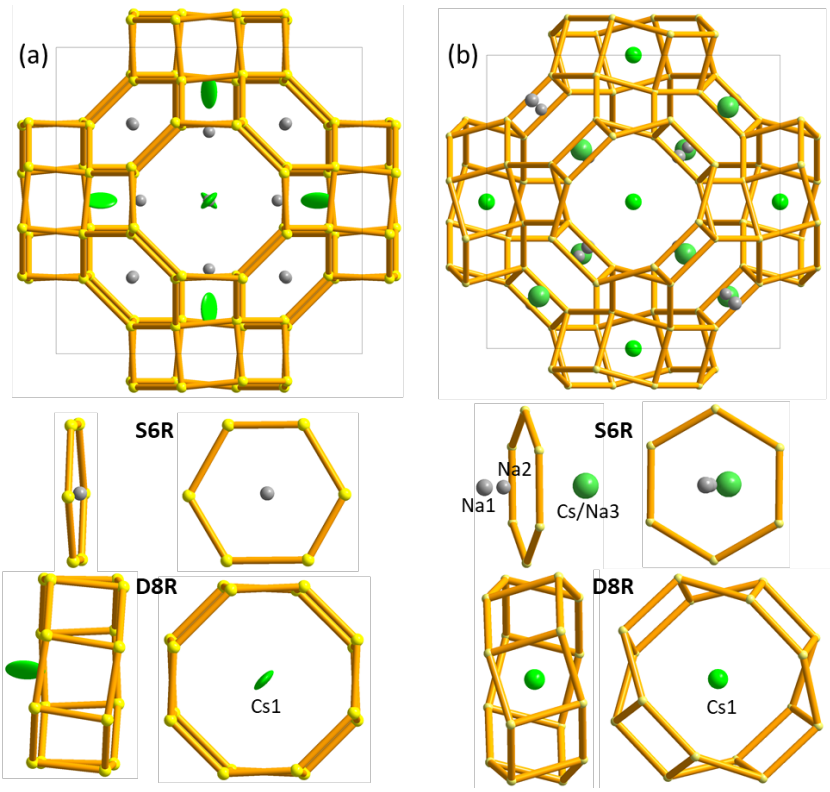

Figure 5. Views of the RHO framework of the two structures (a) NaCs-RHO-1 and (b) NaCs-RHO-2 obtained after dehydration of the as synthesized $\mathrm{NaCs}-\mathrm{RHO}\left(\mathrm{H}_{2} \mathrm{O}\right)$ nanosized zeolite. Ellipsoids are drawn at the $50 \%$ probability level. 
to the presence of water. This means that the structural model we proposed for $\mathrm{NaCs}-\mathrm{RHO}\left(\mathrm{H}_{2} \mathrm{O}\right)$ actually corresponds to an average structure between two hydrated structures with identical unit cell parameters, but with slightly different chemical compositions, and different $\mathrm{Cs}^{+} / \mathrm{Na}^{+}$distributions.

\section{$\mathrm{CO}_{2}$ adsorption study on flexible RHO nanosized zeo- lite.}

The $\mathrm{CO}_{2}$ adsorption process was also followed by in situ TDPXRD (Figure S6). After dehydration under $\mathrm{N}_{2}$ atmosphere at $350{ }^{\circ} \mathrm{C}$ the nanosized zeolite sample was exposed to $\mathrm{CO}_{2}$ at 1 bar at $350{ }^{\circ} \mathrm{C}$. This was followed by a decreasing of the temperature until $30{ }^{\circ} \mathrm{C}$ while maintaining the $\mathrm{CO}_{2}$ atmosphere. The PXRD patterns presented in Figure 7a clearly reveal the presence of the two zeolites, NaCs-RHO-1 and NaCs-RHO-2, after dehydration at $350{ }^{\circ} \mathrm{C}$. Then, during the temperature decrease, the splitting of the reflection completely disappears below 110 ${ }^{\circ} \mathrm{C}$, similar to the behaviour observed for the rehydration process. After cooling the sample to $30{ }^{\circ} \mathrm{C}$ under $\mathrm{CO}_{2}$ atmosphere a single $\mathrm{NaCs}-\mathrm{RHO}\left(\mathrm{CO}_{2}\right)$ phase is obtained. The structure of $\mathrm{NaCs}-\mathrm{RHO}\left(\mathrm{CO}_{2}\right)$ was refined by the Rietveld method from the PXRD pattern recorded at $30^{\circ} \mathrm{C}$, which was recorded immediately after cooling of the sample exposed to $\mathrm{CO}_{2}$ to avoid any moisture contamination. The substructure of the RHO

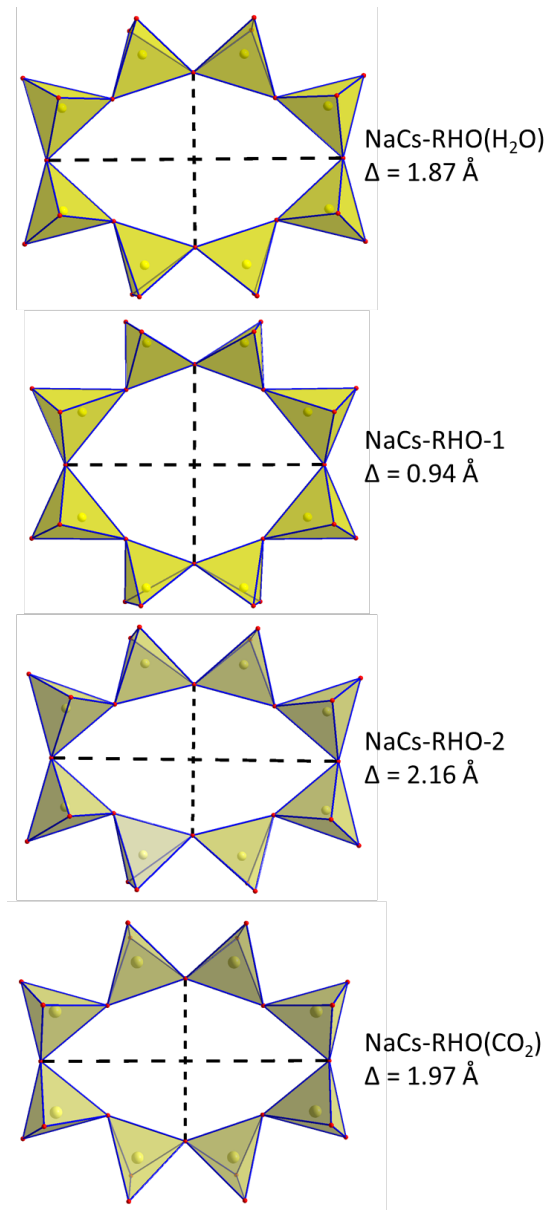

Figure 6. 8-rings elliptical distortions from as synthesized $\mathrm{NaCs}$ $\mathrm{RHO}\left(\mathrm{H}_{2} \mathrm{O}\right)$ nanosized zeolite to the dehydrated forms NaCs-RHO1 and NaCs-RHO-2 and the $\mathrm{CO}_{2}$-sorbed nanozeolite NaCs$\mathrm{RHO}\left(\mathrm{CO}_{2}\right)$. The $\Delta$ parameter is the average of the difference between the two $\mathrm{O}-\mathrm{O}$ distances delineated by dotted lines. (a) $\mathrm{CO}_{2}$ adsorption

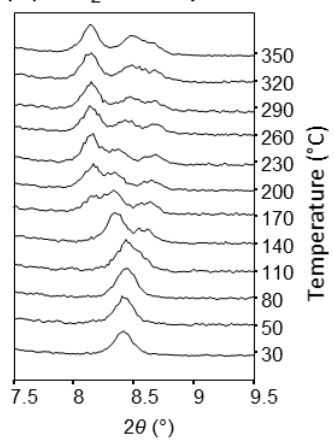

(c)

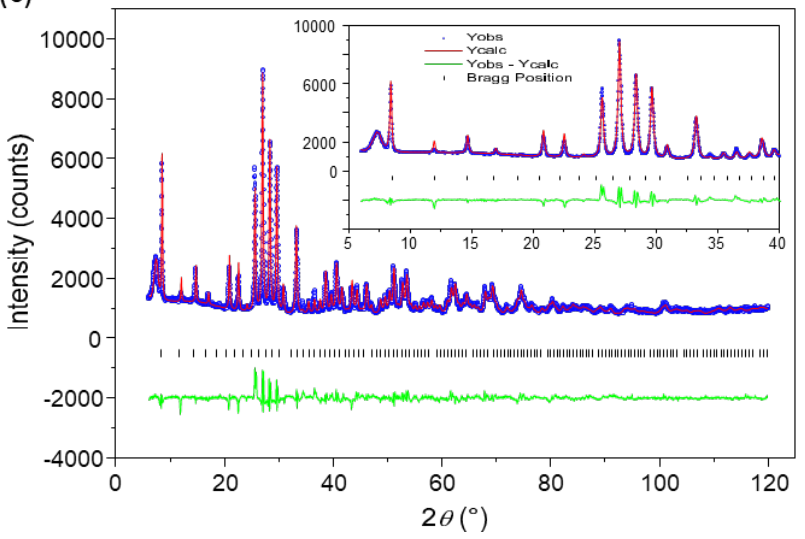

Figure 7. $\mathrm{CO}_{2}$ adsorption process in the nanosized zeolite $\mathrm{NaCs}$ RHO followed in situ by TD-PXRD measurements. (a) PXRD patterns of nanosized NaCs-RHO1-2 zeolites recorded in $\mathrm{CO}_{2}$ atmosphere at 1 bar upon cooling. (b) Views of the RHO framework of the $\mathrm{NaCs}-\mathrm{RHO}\left(\mathrm{CO}_{2}\right)$ structure at room temperature after $\mathrm{CO}_{2}$ adsorption. Ellipsoids are drawn at the $50 \%$ probability level. (c) Rietveld refinement of the PXRD pattern of nanosized NaCs$\mathrm{RHO}\left(\mathrm{CO}_{2}\right)$ zeolite collected at $30^{\circ} \mathrm{C}$ under $\mathrm{CO}_{2}$ atmosphere.

framework was refined and the cationic positions determined in the $I-43 m$ space group, with a cubic unit-cell parameter of $a=$ 14.6937(18) A. However, the $\mathrm{CO}_{2}$ molecules could not be accurately located within the RHO cage. The Fourier difference map clearly revealed residues close to the $\mathrm{Na}^{+}$cations, however the atomic positions of the $\mathrm{CO}_{2}$ molecules could not be satisfactorily refined. The approximate positions of the $\mathrm{CO}_{2}$ molecules were retained in our model to take into account the electronic density present in the RHO cage. Thus, the positions C5, O5 and $\mathrm{O} 6$ of our model should be considered as approximate positions, since the $\mathrm{C}-\mathrm{O}$ distances $(\mathrm{dC} 1-\mathrm{O} 4=1.5626(1) \AA$, $\mathrm{dC} 1-$ $\mathrm{O} 5=1.2977$ (1) $\AA$ ) are longer than those expected for $\mathrm{CO}_{2}(1.16$ $\AA)$. It is likely that the $\mathrm{CO}_{2}$ molecules are disordered around these positions, close to the $\mathrm{Na}^{+}$cations. The final reliability factors obtained after the last refinement cycle are: $\mathrm{R}_{\text {Fobs }}=$ $3.44 \%$ and $\mathrm{R}_{\mathrm{wp}}=6.02 \%$ (see Figure $7 \mathrm{c}$ for the corresponding PXRD fit). All the atomic positions are summarized in Table S1. The elliptical distortion parameter $\Delta=1.97 \AA$ of the D8Rs in the $\mathrm{NaCs}-\mathrm{RHO}\left(\mathrm{CO}_{2}\right)$ structure has an intermediate value between those of the hydrated $\mathrm{NaCs}-\mathrm{RHO}\left(\mathrm{H}_{2} \mathrm{O}\right)$ and dehydrated NaCs-RHO-2 (Figure 6). This is in agreement with the unit-cell parameter $a=14.6937(18) \AA$. This demonstrates that the flexible behaviour of the RHO framework is retained even during the adsorption of $\mathrm{CO}_{2}$. In the $\mathrm{NaCs}-\mathrm{RHO}\left(\mathrm{CO}_{2}\right)$ structure the $\mathrm{Cs}^{+}$ and $\mathrm{Na}^{+}$cations retain similar positions to those of the hydrated structure $\mathrm{NaCs}-\mathrm{RHO}\left(\mathrm{H}_{2} \mathrm{O}\right)$ (Figure $7 \mathrm{~b}$ ), and the cationic composition remains the same, $\mathrm{Cs}_{5.2} \mathrm{Na}_{13.1} \mathrm{Si}_{29.7} \mathrm{Al}_{18.3} \mathrm{O}_{96}\left(\mathrm{CO}_{2}\right)_{18}$. 
In addition to the structural refinement in the presence of $\mathrm{CO}_{2}$, the $\mathrm{CO}_{2}$ adsorption behaviour of the nanosized RHO-type zeolite was also investigated further by adsorption analysis, TGA, and in situ FTIR experiments. The $\mathrm{CO}_{2}$ isotherm recorded up to $900 \mathrm{mmHg}$, corresponding to $1.2 \mathrm{bar}$, is described with a Langmuir shape until $\mathrm{P}=0.4$ bar followed by a nearly linear trend up to $\mathrm{P}=1.2$ bar. At the highest absolute pressure $(\mathrm{P}=1.2 \mathrm{bar}$,
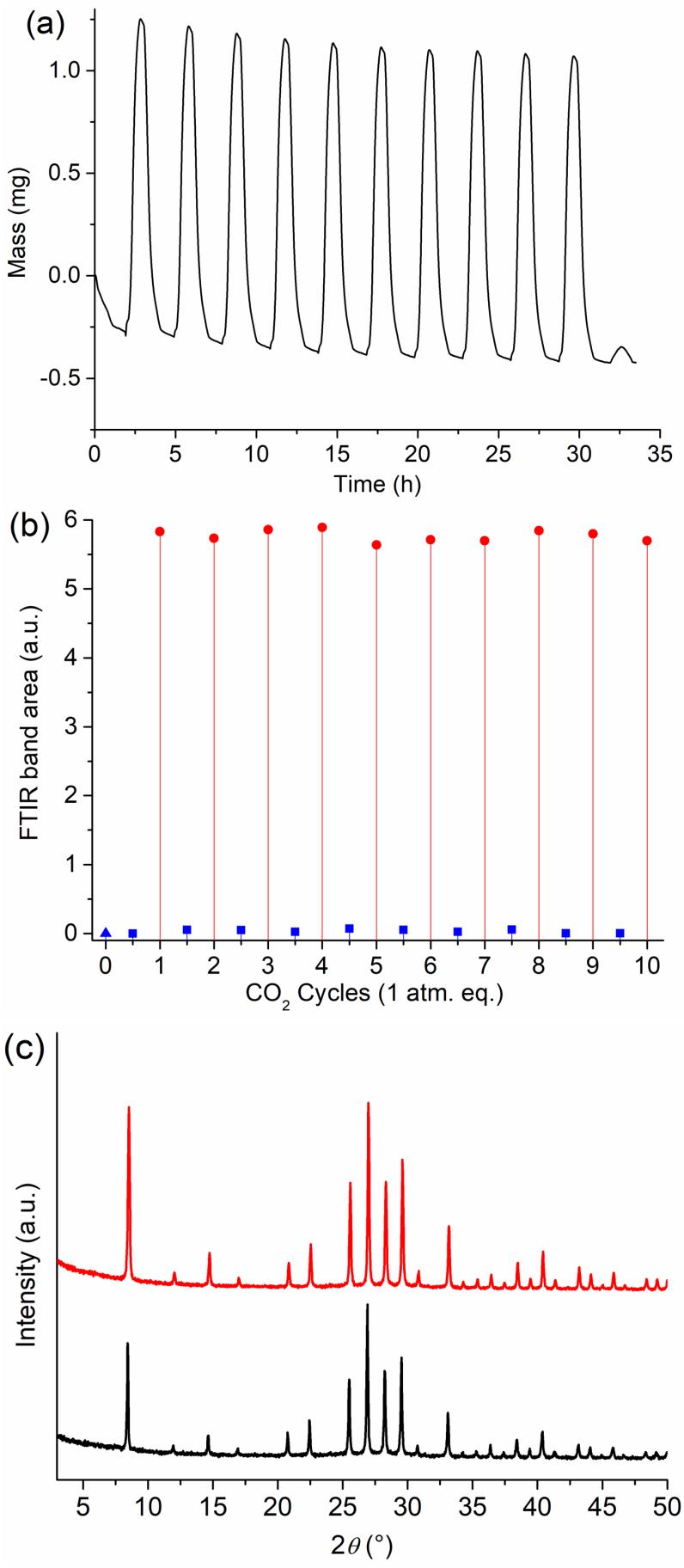

Figure 8. (a) TGA of $\mathrm{NaCs}-\mathrm{RHO}$ under alternating atmospheres of $\mathrm{N}_{2}\left(350{ }^{\circ} \mathrm{C}\right)$ and $\mathrm{CO}_{2}\left(25^{\circ} \mathrm{C}\right)$, (b) integrated band areas of physiand chemisorbed $\mathrm{CO}_{2}$ measured by in situ FTIR of NaCs-RHO under alternating vacuum and $\mathrm{CO}_{2}$ atmosphere (1 bar), activation (blue triangle), adsorption (red circle), desorption (blue square), (c) XRD patterns of $\mathrm{NaCs}-\mathrm{RHO}\left(\mathrm{H}_{2} \mathrm{O}\right)$ before and after TG cycling. $25^{\circ} \mathrm{C}$ ) the RHO nanosized zeolite adsorbed $1.56 \mathrm{mmol} \mathrm{CO}_{2}$ per gram of zeolite (Figure S7). TGA confirmed that $1.37 \mathrm{mmol}$ of $\mathrm{CO}_{2}$ (at 1 bar) per gram of RHO was adsorbed (Figure S8). The stability of the RHO nanosized zeolite under $\mathrm{CO}_{2}$ adsorption was confirmed by performing 10 consecutive cycles of adsorption and desorption under alternating atmospheres of $\mathrm{N}_{2}$ and $\mathrm{CO}_{2}$ (Figure 8a). In addition to the TGA, the stability of the RHO nanosized zeolite was investigated by in situ FTIR (Figure 8 b). Following activation of the sample at $350^{\circ} \mathrm{C}$ under vacuum (blue triangle), the adsorption of $\mathrm{CO}_{2}$ was monitored by the integration of the FTIR bands attributed to physi- and chemisorbed $\mathrm{CO}_{2}$. Multiple cycles of activation and adsorption clearly demonstrate that the adsorption capacity is maintained; the band areas (red circles) reached the same level in all cycles. In addition, the adsorption of $\mathrm{CO}_{2}$ appeared fully reversible as the band area after desorption (blue squares) always returned to the initial value (blue triangle). This result confirmed that the adsorption capacity of the RHO nanosized zeolite is preserved over the 10 cycles. Finally, XRD analysis revealed no loss of crystallinity of the sample after the 10 consecutive cycles of $\mathrm{CO}_{2}$ adsorption/desorption (Figure 8c). To investigate the selectivity of the RHO nanosized zeolite towards $\mathrm{CO}_{2}$ over $\mathrm{CH}_{4}$, in situ IR spectroscopy was performed using a mixture of $\mathrm{CO}_{2}$ and $\mathrm{CH}_{4}$ ( $1 / 1$ in volume) gases $(1 \mathrm{bar})$ delivered to the RHO self-supported pellet. The FTIR spectra collected at different concentrations are presented in Figure $\mathrm{S} 9$. The selective $\mathrm{CO}_{2}$ adsorption in the RHO zeolite is confirmed by the presence of the bands at $2650 \mathrm{~cm}^{-1}$ and $1650 \mathrm{~cm}^{-1}$, corresponding to the physi- and chemisorption $\mathrm{CO}_{2}$ respectively (Figure $\mathrm{S} 9$ ). At the same time, no band in the region 2700-2900 $\mathrm{cm}^{-1}$ corresponding to $\mathrm{CH}_{4}$ adsorption was observed. The rovibrational bands observed centred at $3050 \mathrm{~cm}^{-1}$ are attributed to free $\mathrm{CH}_{4}$ molecules.

\section{CONCLUSIONS}

Flexible small-pore RHO-type nanosized zeolite has been prepared free of OSDAs with a size of individual particles below $100 \mathrm{~nm}$. The RHO nanosized crystals have a Si/Al atomic ratio of 1.50 and high $\mathrm{Cs}^{+}$content that significantly improved the thermal stability up to $550{ }^{\circ} \mathrm{C}$. Variable temperature in situ PXRD experiments reveal the flexibility of the RHO structure upon dehydration. Two different phases have been refined revealing different behavior upon dehydration according to their chemical compositions and different distributions of $\mathrm{Cs}^{+}$and $\mathrm{Na}^{+}$within the unit cell of RHO. The 8-rings elliptical distortions of the as synthesized RHO (hydrated form) of $1.87 \AA$ changed to $0.94 \AA$ and $2.16 \AA$ to two dehydrated RHO forms. The Rietveld refinements of the RHO zeolite revealed the large anisotropic displacement parameters of the $\mathrm{Cs}^{+}$cations along the 8 -fold axis of the D8R. The NaCs-RHO-1 structure shows the ability of the $\mathrm{Cs}^{+}$cation to displace out from and in to the D8R window site. This displacement is the basis of "trapdoor" behavior controlling the selective adsorption capacity of the RHO zeolite. The high stability and selectivity towards $\mathrm{CO}_{2}$ of the RHO-type nanosized zeolites is demonstrated. The integration of the flexible nanosized RHO zeolites in membranes is currently under investigation.

\section{ASSOCIATED CONTENT}

Supporting Information. Contains information pertaining to variable temperature PXRD analysis under $\mathrm{N}_{2}$ for $10 \mathrm{~h}$, XRD pattern after ion-exchange and calcination, $\mathrm{N}_{2}$ adsorption analysis, in situ PXRD analysis in air up to $440{ }^{\circ} \mathrm{C}$, TGA/DTG, $\mathrm{CO}_{2}$ adsorption analysis, in situ FTIR, PXRD data and Rietveld refinement details, 
atomic positions and $\mathrm{U}_{\text {iso-eq }}$ parameters. This material is available free of charge via the Internet at http://pubs.acs.org.

\section{AUTHOR INFORMATION}

\section{Corresponding Authors}

nicolas.barrier@ensicaen.fr

svetlana.mintova@ensicaen.fr

\section{Notes}

The authors declare no competing financial interest.

\section{ACKNOWLEDGMENT}

Financial support from CARNOT ESP, TOTAL and Industrial Chair ANR-TOTAL "Nanoclean Energy" is acknowledged, as well as from the Normandy Region through the RIN Recherche Program.

\section{REFERENCES}

(1) Mintova, S.; Jaber, M.; Valtchev, V., Nanosized microporous crystals: emerging applications. Chem. Soc. Rev. 2015, 44 (20), $7207-$ 7233.

(2) Mintova, S.; Grand, J.; Valtchev, V., Nanosized zeolites: quo vadis? C. R. Chim. 2016, 19 (1-2), 183-191.

(3) Awala, H.; Gilson, J.-P.; Retoux, R.; Boullay, P.; Goupil, J.-M.; Valtchev, V.; Mintova, S., Template-free nanosized faujasite-type zeolites. Nat. Mater. 2015, 14 (4), 447.

(4) Ng, E.-P.; Chateigner, D.; Bein, T.; Valtchev, V.; Mintova, S., Capturing ultrasmall EMT zeolite from template-free systems. Science 2012, 335 (6064), 70-73.

(5) Shin, J.; Jo, D.; Hong, S. B., Rediscovery of the Importance of Inorganic Synthesis Parameters in the Search for New Zeolites. Acc. Chem. Res. 2019.

(6) Ji, Y.; Birmingham, J.; Deimund, M. A.; Brand, S. K.; Davis, M. E., Steam-dealuminated, OSDA-free RHO and KFI-type zeolites as catalysts for the methanol-to-olefins reaction. Microporous Mesoporous Mater. 2016, 232, 126-137.

(7) Ke, Q.; Sun, T.; Cheng, H.; Chen, H.; Liu, X.; Wei, X.; Wang, S., Targeted synthesis of ultrastable high-silica rho zeolite through alkali metal-crown ether interaction. Chem. - Asian J. 2017, 12 (10), 1043-1047.

(8) Nearchou, A.; Sartbaeva, A., Influence of alkali metal cations on the formation of zeolites under hydrothermal conditions with no organic structure directing agents. CrystEngComm 2015, 17 (12), 2496-2503.

(9) Robson, H. E.; Shoemaker, D. P.; Ogilvie, R. A.; Manor, P. C., Synthesis and Crystal Structure of Zeolite Rho-A New Zeolite Retlated to Linde Type A. In Molecular Sieves, Meier M. W., U. J. B., Ed. ACS Publications: 1973; Vol. 121, pp 106-115.

(10) Dusselier, M.; Davis, M. E., Small-pore zeolites: synthesis and catalysis. Chem. Rev. 2018, 118 (11), 5265-5329.

(11) Ji, Y.; Deimund, M. A.; Bhawe, Y.; Davis, M. E. Organic-Free Synthesis of Small Pore Zeolite Catalysts. U.S. Patent 10,173,211 B2, 2016.

(12) Lozinska, M. M.; Mangano, E.; Mowat, J. P.; Shepherd, A. M.; Howe, R. F.; Thompson, S. P.; Parker, J. E.; Brandani, S.; Wright, P. A., Understanding carbon dioxide adsorption on univalent cation forms of the flexible zeolite Rho at conditions relevant to carbon capture from flue gases. J. Am. Chem. Soc. 2012, 134 (42), 17628-17642.

(13) Palomino, M.; Corma, A.; Jordá, J. L.; Rey, F.; Valencia, S., Zeolite Rho: a highly selective adsorbent for $\mathrm{CO}_{2} / \mathrm{CH}_{4}$ separation induced by a structural phase modification. Chem. Commun. 2012, 48 (2), 215-217.

(14) Min, J. G.; Kemp, K. C.; Lee, H.; Hong, S. B., $\mathrm{CO}_{2}$ Adsorption in the RHO Family of Embedded Isoreticular Zeolites. J. Phys. Chem. $C$ 2018, 122 (50), 28815-28824.

(15) Goldyn, K.; Anfray, C.; Komaty, S.; Ruaux, V.; Hélaine, C.; Retoux, R.; Valable, S.; Valtchev, V.; Mintova, S., Copper exchanged FAU nanozeolite as non-toxic nitric oxide and carbon dioxide gas carrier. Microporous Mesoporous Mater. 2019, 280, 271-276.

(16) Lozinska, M. M.; Mowat, J. P.; Wright, P. A.; Thompson, S. P.; Jorda, J. L.; Palomino, M.; Valencia, S.; Rey, F., Cation gating and relocation during the highly selective "trapdoor" adsorption of $\mathrm{CO}_{2}$ on univalent cation forms of zeolite rho. Chem. Mater. 2014, 26 (6), 20522061.

(17) De Baerdemaeker, T.; De Vos, D., Gas separation: trapdoors in zeolites. Nat. Chem. 2013, 5 (2), 89.

(18) Coudert, F.-X.; Kohen, D., Molecular insight into $\mathrm{CO}_{2}$ "trapdoor" adsorption in zeolite Na-RHO. Chem. Mater. 2017, 29 (7), 2724-2730.

(19) Corbin, D. R.; Abrams, L.; Jones, G.; Eddy, M.; Harrison, W.; Stucky, G.; Cox, D., Flexibility of the zeolite RHO framework: in situ $\mathrm{x}$-ray and neutron powder structural characterization of divalent cationexchanged zeolite RHO. J. Am. Chem. Soc. 1990, 112 (12), 4821-4830.

(20) Pera-Titus, M.; Palomino, M.; Valencia, S.; Rey, F., Thermodynamic analysis of framework deformation in Na, Cs-RHO zeolite upon $\mathrm{CO}_{2}$ adsorption. PCCP 2014, 16 (44), 24391-24400.

(21) Balestra, S. R.; Hamad, S.; Ruiz-Salvador, A. R.; DomínguezGarcía, V.; Merkling, P. J.; Dubbeldam, D.; Calero, S., Understanding nanopore window distortions in the reversible molecular valve zeolite RHO. Chem. Mater. 2015, 27 (16), 5657-5667.

(22) Guo, X.; Corbin, D. R.; Navrotsky, A., Thermodynamics of $\mathrm{H}_{2} \mathrm{O}$ and $\mathrm{CO}_{2}$ Absorption and Guest-Induced Phase Transitions in Zeolite RHO. J. Phys. Chem. C 2018, 122 (35), 20366-20376.

(23) Petříček, V.; Dušek, M.; Palatinus, L., Crystallographic computing system JANA2006: general features. Z. Kristallogr. - Cryst. Mater. 2014, 229 (5), 345-352.

(24) Palatinus, L.; Chapuis, G., SUPERFLIP-a computer program for the solution of crystal structures by charge flipping in arbitrary dimensions. J. Appl. Crystallogr. 2007, 40 (4), 786-790.

(25) Parise, J. B.; Prince, E., The structure of cesium-exchanged zeolite-RhO at $293 \mathrm{~K}$ and $493 \mathrm{~K}$ determined from high resolution neutron powder data. Mater. Res. Bull. 1983, 18 (7), 841-852.

(26) Baur, W. H.; Bieniok, A.; Shannon, R. D.; Prince, E., Neutron powder diffraction study of a $\mathrm{Na}$, Cs-Rho zeolite. Z. Kristallogr. Cryst. Mater. 1989, 187 (1-4), 253-266.

(27) Georgieva, V. M.; Bruce, E. L.; Verbraeken, M. C.; Scott, A. R.; Casteel Jr, W. J.; Brandani, S.; Wright, P. A., Triggered Gate Opening and Breathing Effects during Selective $\mathrm{CO} 2$ Adsorption by Merlinoite Zeolite. J. Am. Chem. Soc. 2019, 141 (32), 12744-12759.

(28) Lee, Y.; Hriljac, J. A.; Vogt, T.; Parise, J. B.; Edmondson, M. J.; Anderson, P. A.; Corbin, D. R.; Nagai, T., Phase transition of zeolite RHO at high-pressure. J. Am. Chem. Soc. 2001, 123 (34), 8418-8419. 
Insert Table of Contents artwork here

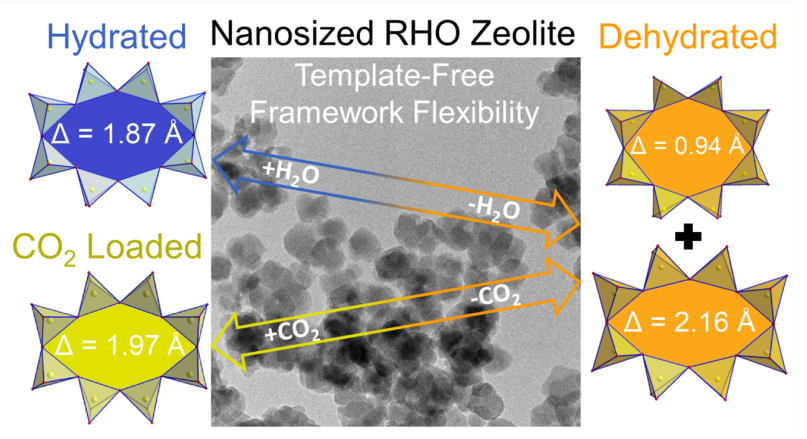

